\title{
Characterization and Membrane Assembly of the TatA Component of the Escherichia coli Twin-Arginine Protein Transport System ${ }^{\dagger}$
}

Ida Porcelli, ${ }^{\ddagger}{ }^{\S}$ Erik de Leeuw, ${ }^{\ddagger}$, Russell Wallis, ${ }^{\ddagger}$ Els van den Brink-van der Laan," Ben de Kruijff," B. A. Wallace, ${ }^{\perp}$ Tracy Palmer, ${ }^{@}$ and Ben C. Berks*,

Department of Biochemistry, University of Oxford, South Parks Road, Oxford OX1 3QU, United Kingdom, Institute of Biomembranes, Department of Biochemistry of Membranes, Centre for Biomembranes and Lipid Enzymology, Utrecht University, Padualaan 8, 3584 CH Utrecht, The Netherlands, School of Crystallography, Birkbeck College, University of London, Malet Street, London WCIE 7HX, United Kingdom, and Department of Molecular Microbiology, John Innes Centre, Norwich NR4 7UH, United Kingdom

Received May 16, 2002; Revised Manuscript Received July 25, 2002

\begin{abstract}
Proteins bearing a signal peptide with a consensus twin-arginine motif are translocated via the Tat pathway, a multiprotein system consisting minimally of the integral inner membrane proteins TatA, TatB, and TatC. On a molar basis, TatA is the major pathway component. Here we show that TatA can be purified independently of the other Tat proteins as a $460 \mathrm{kDa}$ homooligomeric complex. Homooligomer formation requires the amino-terminal membrane-anchoring domain of TatA. According to circular dichroism spectroscopy, approximately half of the TatA polypeptide forms $\alpha$-helical secondary structure in both detergent solution and proteoliposomes. An expressed construct without the transmembrane segment is largely unstructured in aqueous solution but is able to insert into phospholipid monolayers and interacts with membrane bilayers. Protease accessibility experiments indicate that the extramembranous region of TatA is located at the cytoplasmic face of the cell membrane.
\end{abstract}

The majority of bacterial periplasmic proteins are exported across the cytoplasmic membrane by the Sec pathway (1, 2). However, a subset of periplasmic proteins, including many that bind redox-active cofactors, are translocated by a distinct Sec-independent mechanism. Such proteins are synthesized with $\mathrm{N}$-terminal signal sequences containing a consensus S-R-R-X-F-L-K motif in which the arginine residues are (almost) invariant (3). These "twin-arginine" signal peptides target the precursor protein to the Tat (twinarginine translocation) protein export system $(4,5)$ which is mechanistically and structurally related to the $\Delta \mathrm{pH}$-dependent thylakoid import pathway of chloroplasts (6). Translocation by the Sec system occurs by a threading mechanism in which the substrate must adopt an extended conformation. In contrast, the Tat system functions to transport folded proteins across the cytoplasmic membrane, a feat that must be

\footnotetext{
$\dagger$ This work was supported by the Commission of the European Community through the programme "ExporteRRs". I.P. is the recipient of a graduate studentship from the Department of Biochemistry, University of Oxford. T.P. is a Royal Society University Research Fellow, and B.C.B. is the R. J. P. Williams Senior Research Fellow at Wadham College, Oxford. Funding for the analytical ultracentrifuge facility was provided by grants from the Wellcome Trust and the Biotechnology and Biological Sciences Research Council. The circular dichroism instrumentation was supported, in part, by Grant B14225 from the Biotechnology and Biological Sciences Research Council.

* To whom correspondence should be addressed: Department of Biochemistry, University of Oxford, South Parks Road, Oxford OX1 3QU, United Kingdom. Telephone: +44 (0)1865 275250. Fax: +44 (0)1865 275259. E-mail: ben.berks@bioch.ox.ac.uk.

$\doteqdot$ University of Oxford.

$\S$ These authors contributed equally to this work.

" Utrecht University.

${ }^{\perp}$ University of London.

${ }^{\circledR}$ John Innes Centre.
}

achieved without rendering the membrane freely permeable to protons or other ions.

In Escherichia coli, the integral membrane proteins TatA, TatB, TatC, and TatE have been shown to be components of the Tat pathway (7-12). All except TatC are sequencerelated proteins. Genetic experiments have shown TatA and TatE to have overlapping functions on the Tat pathway, while TatB is an essential Tat component with a distinct role in protein export $(8,9)$. Expression studies suggest that tatE may be a cryptic gene duplication of tatA (13).

TatA is present at an approximately 20 -fold molar excess over the other essential Tat components, TatB and TatC (11, 13). Chemical cross-linking studies have shown that TatA forms at least tetrameric homooligomers in the cytoplasmic membrane (12), while purification experiments suggest that TatA associates with TatB and TatC in at least two types of large (approximately $600 \mathrm{kDa}$ ) macromolecular complexes $(11,14)$. Work with the plant Tat system indicates that TatA is required for the transport steps that follow precursor recognition at the membrane $(15,16)$, while electron microscopic analysis of an E. coli TatAB complex suggests that TatA may form the protein transporting channel (11). TatA is thus arguably both the major and most important component of the Tat pathway. Here we report the purification and characterization of TatA in the absence of other Tat components. We also describe the isolation and analysis of a water-soluble fragment of the TatA protein formed by removing the membrane anchor domain.

\section{MATERIALS AND METHODS}

Cell Growth, Protein Expression and Fractionation. All strains were grown aerobically at $37{ }^{\circ} \mathrm{C}$ in $\mathrm{LB}$ medium 
supplemented with appropriate antibiotics (8). Plasmid pFAT584 (12) was used for the overproduction of TatA with a carboxy-terminal hexahistidine tag, and plasmid pFAT587 (12) was used for the overproduction of a variant TatA protein (designated $\triangle \mathrm{TMS}$-TatA) in which the predicted amino-terminal transmembrane helix is replaced with a hexahistidine sequence. Each plasmid was individually transformed into E. coli strain C43(DE3) (17) harboring pREP4 (Kan ${ }^{\mathrm{R}}$, lacI $^{+}$, Roche Molecular Biochemicals) and cultured to midexponential phase. Expression of the recombinant protein was induced by isopropyl 1-thio- $\beta$-D-galactopyranoside (IPTG) at a final concentration of $2 \mathrm{mM}$. After $3 \mathrm{~h}$, cells were harvested by centrifugation $(7000 \mathrm{~g}$ for 20 min) and resuspended in $20 \mathrm{mM}$ MOPS ( $\mathrm{pH} 7.2$ ) and 200 $\mathrm{mM} \mathrm{NaCl}$ (buffer A) supplemented with DNase I and lysozyme. Cells were disrupted by being passed twice through a French pressure cell at 5000 psi in the same buffer supplemented with protease inhibitors (Complete, Roche Molecular Biochemicals). Crude soluble and membrane fractions were obtained by differential centrifugation as described previously (8).

For the protease accessibility experiments, strain MC4100 (18) harboring pREP4 was used as the wild-type strain while cells containing in addition plasmid pFAT584 or pFAT75 (11) were used to overexpress TatA or TatABCDE, respectively. Strain BL21(DE3) containing pET21d-Lep was used for expression of leader peptidase. Spheroplasts were prepared by resuspending the cell pellet in $2.5 \mathrm{~mL}$ of $33 \mathrm{mM}$ Tris-HCl ( $\mathrm{pH} \mathrm{8.0),} 40 \%$ sucrose, and $5 \mathrm{mM} \mathrm{Na}_{2}$ EDTA (0.1 $\mathrm{mg} / \mathrm{mL}$ ). Cells were incubated at $4{ }^{\circ} \mathrm{C}$ for $30 \mathrm{~min}$ and then harvested at $7000 \mathrm{~g}$ for $15 \mathrm{~min}$. The resulting spheroplast pellet was resuspended in $1 \mathrm{~mL}$ of ice-cold $33 \mathrm{mM}$ Tris$\mathrm{HCl}(\mathrm{pH} 8.0)$ and $40 \%$ sucrose. Inverted inner membrane vesicles (IMVs) ${ }^{1}$ were prepared by sucrose density gradient centrifugation as previously described (19).

Purification of TatA. The crude membrane fraction from cells overexpressing TatA from plasmid pFAT584 was solubilized at a final protein concentration of $5 \mathrm{mg} / \mathrm{mL}$ for $1 \mathrm{~h}$ at $4{ }^{\circ} \mathrm{C}$ in buffer A containing $1 \%$ (w/v, final concentration) nonapolyoxyethylene dodecyl ether $\left(\mathrm{C}_{12} \mathrm{E}_{9}\right.$, Sigma). Insoluble material was removed by centrifugation at $150000 \mathrm{~g}$ for $30 \mathrm{~min}$, and the cleared supernatant was applied to a $\mathrm{Ni}^{2+}$-loaded $5 \mathrm{~mL}$ HiTrap Chelating HP column (Amersham-Pharmacia Biotech) equilibrated in buffer A containing $0.1 \% \mathrm{C}_{12} \mathrm{E}_{9}$ and $20 \mathrm{mM}$ imidazole. The column was washed with $25 \mathrm{~mL}$ of buffer A containing $0.1 \% \mathrm{C}_{12} \mathrm{E}_{9}$ and $150 \mathrm{mM}$ imidazole and then developed in $20 \mathrm{~mL}$ of the same buffer with a linear gradient of imidazole to a final concentration of $750 \mathrm{mM}$. TatA-containing fractions were identified by SDS-PAGE, pooled, and concentrated by ultrafiltration using a YM3 membrane (Amicon). The concentrated sample was applied to a Superdex 200 HR 10/ 30 gel permeation column (Amersham Pharmacia Biotech) pre-equilibrated in buffer $\mathrm{A}$ containing $0.1 \% \mathrm{C}_{12} \mathrm{E}_{9}$ and 1 $\mathrm{mM}$ EDTA and then developed in the same buffer. TatAcontaining fractions were again identified by SDS-PAGE analysis. The yield of purified TatA was $4 \mathrm{mg}$ of protein from each liter of bacterial cell culture.

\footnotetext{
${ }^{1}$ Abbreviations: $\mathrm{C}_{12} \mathrm{E}_{9}$, nonapolyoxyethylene dodecyl ether; IMV, inner membrane vesicle.
}

Purification of $\triangle T M S$-TatA. The soluble fraction from cells overexpressing $\triangle$ TMS-TatA was applied to a $\mathrm{Ni}^{2+}$-loaded 5 mL HiTrap Chelating HP column (Amersham-Pharmacia Biotech) equilibrated in $10 \mathrm{mM}$ Tris- $\mathrm{HCl}(\mathrm{pH}$ 7.5) containing $20 \mathrm{mM}$ imidazole. The column was then washed with 25 $\mathrm{mL}$ of $10 \mathrm{mM}$ Tris- $\mathrm{HCl}(\mathrm{pH} 7.5)$ and $20 \mathrm{mM}$ imidazole, and bound proteins were eluted in a further $20 \mathrm{~mL}$ of buffer containing a linear gradient of imidazole to a final concentration of $750 \mathrm{mM}$. Fractions containing the purified protein were identified by SDS-PAGE. The yield of purified $\triangle$ TMS-TatA was $2.5 \mathrm{mg}$ of protein from each liter of bacterial cell culture.

Analytical Ultracentrifugation. All experiments were carried out in a Beckman Optima XL-A analytical ultracentrifuge equipped with absorbance optics using an An60Ti rotor. Sedimentation equilibrium experiments were performed at $5000-7000 \mathrm{rpm}$ for TatA or 30000-35000 rpm for $\Delta$ TMSTatA. Data were collected at 280 (TatA) or $238 \mathrm{~nm}(\Delta$ TMSTatA) in step scan mode using a separation of $0.001 \mathrm{~cm}$. Five readings were averaged for each scan, and a baseline scan was taken at $360 \mathrm{~nm}$ to correct for optical imperfections. Readings were taken at $6 \mathrm{~h}$ intervals until no difference could be detected between consecutive scans. The equilibrium distributions from three different loading concentrations and up to three different rotor speeds were analyzed simultaneously using the Nonlin curve algorithm supplied with the centrifuge (20). Data were also analyzed by calculation of the apparent weight-average molecular mass at concentrations throughout the sample cells. The partial specific volumes of the proteins were calculated from the amino acid composition using the method of Cohn and Edsall (21). For the sedimentation equilibrium experiments involving $\mathrm{C}_{12} \mathrm{E}_{9}$-purified TatA, the solvent density was adjusted to that of the detergent by adding $57 \%(\mathrm{v} / \mathrm{v}) \mathrm{D}_{2} \mathrm{O}(22)$, and a figure of $1.059 \mathrm{~g} / \mathrm{mL}$ was used for the density of $\mathrm{C}_{12} \mathrm{E}_{9}$ (23).

Circular Dichroism (CD) Spectroscopy. CD spectra were recorded on an Aviv 62ds spectropolarimeter equipped with a variable-position detector for use with scattering samples. The spectra reported have been obtained with a maximum acceptance angle of $90^{\circ}$. All spectra were collected over a wavelength range from 190 to $300 \mathrm{~nm}$ using a step size of $0.2 \mathrm{~nm}$. A Supracil $0.01 \mathrm{~cm}$ optical path length cell (Hellma Ltd.) was used. Spectra that were obtained were the result of averaging five scans for each preparation. Dynode voltages for the first and last scans of a set were checked for consistency to ensure that no significant variation occurred during data collection. Equivalent numbers of scans of the baseline samples were obtained, averaged, and subtracted from the averaged sample spectra. Spectra were then smoothed using a Savitsky-Golay filter (24). Data were analyzed using DICHROWEB (25). An Nrmsd parameter (26), which is a measure of the goodness of fit, was calculated. Nrmsd values of $\leq 0.1$ are usually indicative of a close correspondence between the calculated structure and the experimental data (27). The best fits were obtained using the program CDSSTR (28) and reference set 7. However, other programs and reference sets gave comparable fits and calculated secondary structures.

Preparation of TatA-Containing Proteoliposomes. A 40 $\mathrm{mg} / \mathrm{mL}$ solution of $E$. coli total membrane polar lipids (Avanti Polar Lipids) containing $1 \%(\mathrm{v} / \mathrm{v}) \mathrm{C}_{12} \mathrm{E}_{9}$ was mixed with purified TatA to give a lipid:protein molar ratio of 100 : 


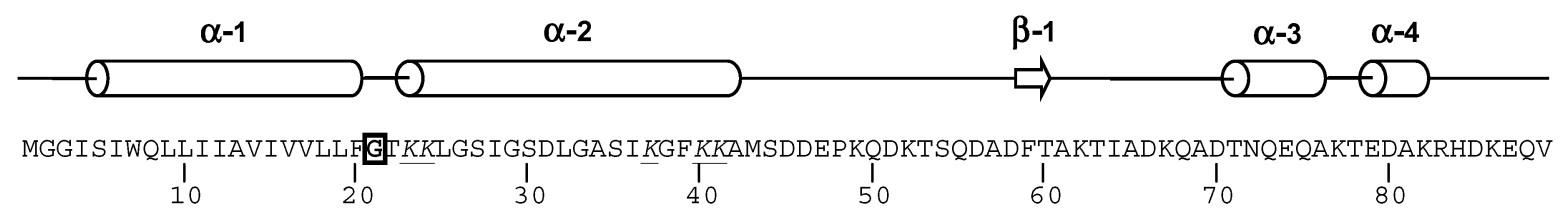

FIGURE 1: Predicted secondary structure elements of the E. coli TatA protein. The prediction is that of the program PSIPRED (32). $\alpha$-Helical regions are represented as cylinders and $\beta$-strands as arrows. It should be noted that only helices $\alpha-1$ and $\alpha-2$ are predicted with a high level of $(>80 \%)$ confidence. The invariant glycine residue (Gly21) is boxed, while basic residues in the predicted amphipathic helix are underlined.

1. Detergent was removed by extensive dialysis against buffer A across a membrane having a nominal molecular mass cutoff of $6-8 \mathrm{kDa}$. Proteoliposomes were collected by ultracentrifugation and washed two times in the same buffer. Prior to use, the proteoliposomes were sonicated three times for $10 \mathrm{~s}$ on ice. Phospholipid vesicles for use in the $\Delta \mathrm{TMS}$ TatA binding experiments and for background subtraction in the $\mathrm{CD}$ measurements were prepared from detergentsolubilized E. coli polar lipids in an analogous manner.

Monolayer Experiments. The monolayer surface pressure was measured by the platinum Wilhelmy plate method (29), using a Cahn 2000 microbalance. The subphase was continuously stirred with a magnetic bar. Purified $\triangle$ TMS-TatA (30 $\mu \mathrm{g}$ for each measurement) was added to the subphase through a hole in the edge of the dish. The pressure changes were followed until the surface pressure increase had reached a maximal value, usually within $30 \mathrm{~min}$. The monomolecular lipid layers were spread from a chloroform solution to give an initial surface pressure between 20 and $42 \mathrm{mN} / \mathrm{m}$. A subphase buffer of $10 \mathrm{mM}$ Tris- $\mathrm{HCl}(\mathrm{pH} 7.5)$ was used at a temperature of $28 \pm 1^{\circ} \mathrm{C}$. The buffer used for the monolayer experiments was filtered through a $22 \mu \mathrm{m}$ pore filter and degassed prior to use. The Teflon dish had a volume of 5 $\mathrm{mL}$ and a surface area of $8.81 \mathrm{~cm}^{2}$.

General Analytical Methods. SDS-PAGE and immunoblotting were carried out as described previously $(30,31)$, and immunoreactive bands were visualized with the ECL detection system (Amersham Pharmacia Biotech). Immunoaffinity-purified anti-TatA antibodies were prepared as described previously (11). Antibody directed against leader peptidase was a kind gift of J.-W. de Gier (University of Stockholm, Stockholm, Sweden).

\section{RESULTS}

Purification and the Oligomeric State of TatA. The TatA protein of $E$. coli is an 89-amino acid membrane protein. The secondary structural elements of this protein were predicted (Figure 1) using the program PSIPRED (32). TatA is strongly predicted to contain a transmembrane $\alpha$-helix at the amino terminus (helix $\alpha-1$ ) followed by a polypeptide segment containing a basic amphipathic $\alpha$-helix (helix $\alpha-2$ ). These predicted helical regions exhibit a high level of sequence conservation between species. However, only a glycine residue between the predicted helices is invariant $(4,33)$ (Figure 1). The secondary structure for the poorly conserved carboxy-terminal half of TatA is less reliably predicted but suggests that this part of the molecule will contain additional helical elements.

To obtain insight into the structural properties and oligomeric state of TatA, we undertook purification of the TatA protein in detergent solution. A hexahistidine sequence was engineered onto the carboxy terminus of Tat $\mathrm{A}$ and the resulting tagged protein overproduced in a wild-type tat background. Membranes from the overexpressing strain were solubilized in the nonionic detergent nonapolyoxyethylene dodecyl ether $\left(\mathrm{C}_{12} \mathrm{E}_{9}\right)$, and the recombinant TatA protein was purified by successive $\mathrm{Ni}^{2+}$-affinity and gel permeation chromatography steps (Figure 2). The identity of the purified protein was confirmed by immunoblotting (data not shown). Neither TatB nor TatC could be detected in the purified TatA fractions by immunoblotting (data not shown). Indeed, an identical (but lower-yield) preparation of TatA could be purified by the same methodology following expression of TatA in the completely Tat-deficient strain DADE (MC4100 $\triangle t a t A B C D \Delta t a t E)(34)$.

Purified TatA was eluted as a single peak from the gel permeation column at a position in the chromatograph corresponding to an apparent molecular mass of $320 \mathrm{kDa}$ (Figure 2B). Since the molecular mass of a histidine-tagged TatA protomer is $10730 \mathrm{Da}$, the purified TatA protein is a homooligomeric complex. To obtain a more accurate estimate of the molecular mass of the TatA complex, the purified TatA protein was subject to analytical ultracentrifugation. TatA sedimented as a single major species in sedimentation velocity experiments (not shown). Sedimentation equilibrium analysis of two independent preparations of TatA gave a weight-average molecular mass of $460 \pm 20 \mathrm{kDa}$. These experiments were carried out under conditions in which the solvent and detergent densities were matched, thereby eliminating the contribution of bound detergent to the observed TatA molecular mass. The hydrodynamic data therefore suggest that each TatA complex contains $43 \pm 2$ TatA protomers. A plot of the apparent molecular mass against protein concentration in the ultracentrifuge cell shows that the molecular mass of the TatA complex is independent of concentration over the range that was examined (Figure $3 \mathrm{~A})$.

We found previously that deletion of the amino-terminal amino acids of TatA corresponding to predicted transmembrane helix $\alpha-1$ changed the localization of TatA from the inner membrane to the cytoplasm (12). To investigate the effect of this deletion on the oligomeric state of the residual water-soluble domain, we undertook purification of this $\Delta$ TMS-TatA protein. A hexahistidine sequence was engineered onto the amino terminus of the truncated protein to allow purification of the protein by $\mathrm{Ni}^{2+}$-affinity chromatography. The protein was purified to homogeneity from the membrane-free soluble extract (Figure 4). The native molecular mass of purified $\Delta \mathrm{TMS}$-TatA was determined to be $9.0 \pm 0.9 \mathrm{kDa}$ by sedimentation equilibrium experiments. Since the mass of the $\Delta$ TMS-TatA polypeptide is $9142 \mathrm{Da}$, this indicates that the truncated TatA protein is a monomer. A plot of the apparent molecular mass versus protein concentration in the centrifuge cell shows no indication of self-association in the concentration range that was analyzed (Figure 3B). Taken together, these data indicate that predicted 

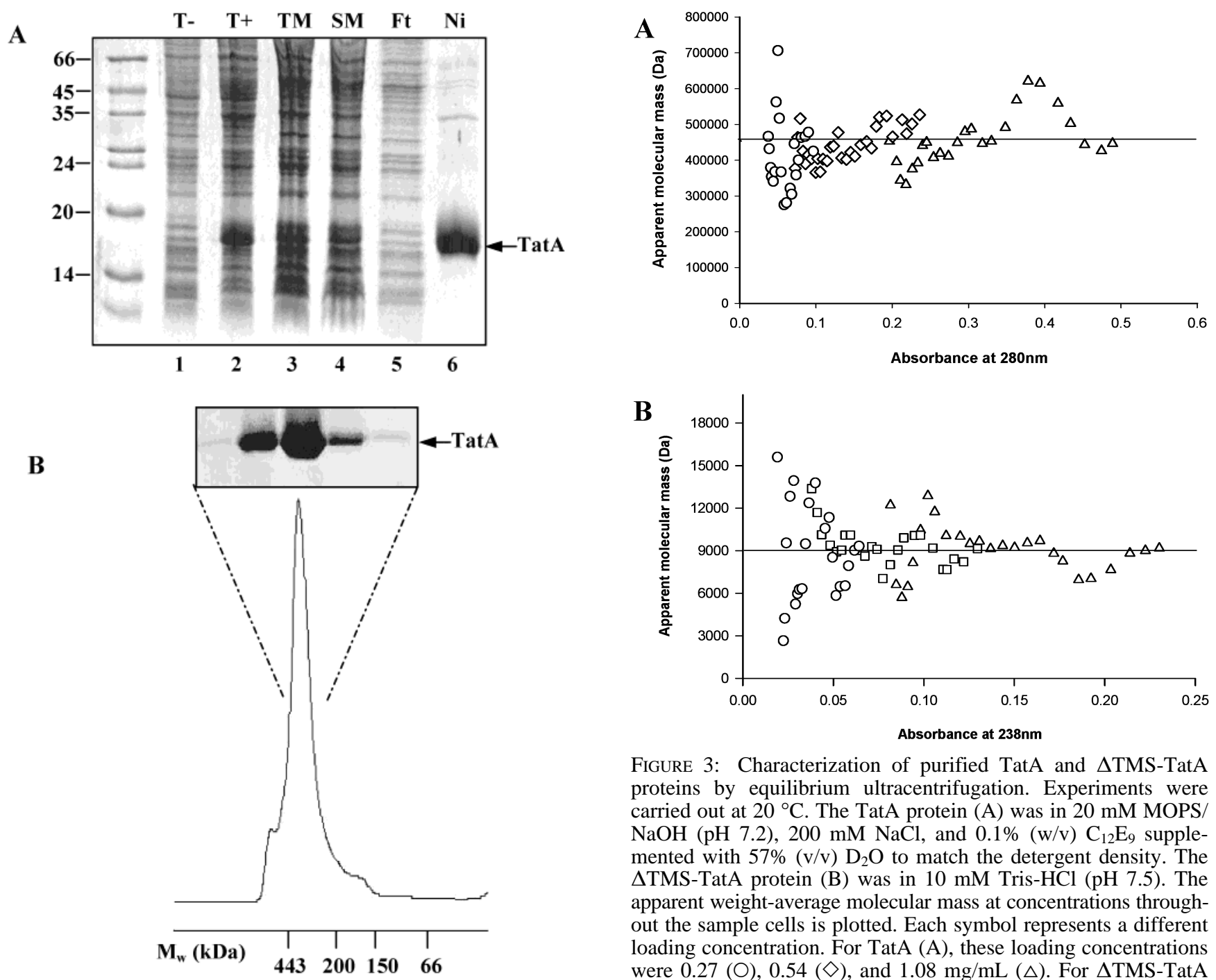

FIGURE 3: Characterization of purified TatA and $\Delta$ TMS-TatA proteins by equilibrium ultracentrifugation. Experiments were carried out at $20^{\circ} \mathrm{C}$. The TatA protein (A) was in $20 \mathrm{mM}$ MOPS/ $\mathrm{NaOH}(\mathrm{pH} 7.2), 200 \mathrm{mM} \mathrm{NaCl}$, and $0.1 \%$ (w/v) $\mathrm{C}_{12} \mathrm{E}_{9}$ supplemented with $57 \%(\mathrm{v} / \mathrm{v}) \mathrm{D}_{2} \mathrm{O}$ to match the detergent density. The $\Delta$ TMS-TatA protein (B) was in $10 \mathrm{mM}$ Tris- $\mathrm{HCl}(\mathrm{pH} 7.5)$. The apparent weight-average molecular mass at concentrations throughout the sample cells is plotted. Each symbol represents a different loading concentration. For TatA (A), these loading concentrations were $0.27(\bigcirc), 0.54(\diamond)$, and $1.08 \mathrm{mg} / \mathrm{mL}(\triangle)$. For $\Delta \mathrm{TMS}$-TatA (B), these loading concentrations were $0.2(\bigcirc), 0.4(\square)$, and 0.8 $\mathrm{mg} / \mathrm{mL}(\triangle)$. The solid line shows the weight-average molecular mass determined for each protein.

polypeptides present at various stages in the purification of TatA. Samples were separated by SDS-PAGE and proteins visualized by Coomassie brilliant blue staining. Each lane contains material derived from the same initial mass of cells. Lanes 1 and 2 are cells of strain C43(DE3) carrying the plasmid pFAT584 either left uninduced $(\mathrm{T}-)$ or induced $(\mathrm{T}+)$ with IPTG for TatA overexpression. Lanes 3-6 show further processing of the cells in lane 2. Lane 3 is the total membrane fraction (TM); lane 4 contains the membrane protein solubilized by the detergent $\mathrm{C}_{12} \mathrm{E}_{9}(\mathrm{SM})$, and lanes 5 and 6 contain the proteins from the soluble extract that either were not retained $(\mathrm{Ft})$ or bound to $(\mathrm{Ni})$ the $\mathrm{Ni}^{2+}$-affinity column. The molecular masses in kilodaltons of standard proteins are shown at the left side of the gel. (B) Characterization of TatA by gel permeation chromatography. Pooled TatA-containing fractions from the $\mathrm{Ni}^{2+}$-affinity column were further purified by gel permeation chromatography on a Superdex-200 column. The 280 $\mathrm{nm}$ absorbance of the column eluant is plotted. Fractions across the peak of the elution profile were analyzed by SDS-PAGE, and the TatA protein was visualized by Coomassie brilliant blue staining. The molecular masses in kilodaltons of water-soluble standard proteins are indicated. The standards were apoferritin $(443 \mathrm{kDa})$, $\beta$-amylase $(200 \mathrm{kDa})$, alcohol dehydrogenase $(150 \mathrm{kDa})$, and bovine serum albumin $(66 \mathrm{kDa})$.

transmembrane helix $\alpha-1$ is required for stable TatA self interactions.

Secondary Structure of TatA. CD spectroscopy was used to analyze the secondary structure elements of the purified TatA complex (Figure 5A). The CD spectrum of TatA in detergent solution has the appearance of a protein dominated

by helical elements with peaks at 190, 208, and $224 \mathrm{~nm}$. Secondary structure analysis of the spectrum indicated that it is comprised of approximately $50 \% \alpha$-helix and a low $\beta$-sheet content (Table 1). These proportions of secondary structure are consistent with the sequence-based predictions shown in Figure 1.

To determine the effect of a membrane environment on the secondary structure of TatA, proteoliposomes were formed by the co-reconstitution of purified TatA with total E. coli polar lipids. The TatA CD spectrum in membrane bilayers was similar to that of the protein in detergent solution (Figure 5A), and there are no significant differences in secondary structure in the two environments (Table 1). Thus, at least in terms of net secondary structure content, TatA has a similar conformation in detergent solution and in a phospholipid environment.

The CD spectrum of $\Delta$ TMS-TatA (Figure $5 \mathrm{~B}$ ) is clearly very different from that of full-length TatA. Secondary structure analysis suggests that $80 \%$ of the polypeptide is in an "other" conformation which is usually indicative of an unfolded protein. The $\alpha$-helix content is less than $10 \%$, rather than the $35 \%$ predicted by subtraction of an 18 -amino acid helix from the CD-determined $\alpha$-helix content of full-length 


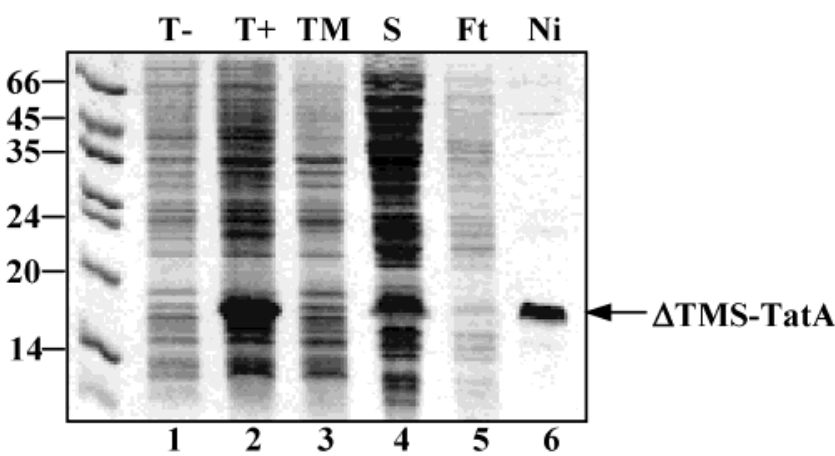

FIGURE 4: Affinity purification of $\Delta$ TMS-TatA. Fractions during the purification of $\triangle$ TMS-TatA were subjected to analysis by SDSPAGE with proteins visualized by Coomassie brilliant blue staining. Each lane contains material derived from the same initial mass of cells. Lanes 1 and 2 are cells of strain C43(DE3) carrying the plasmid pFAT587 either left uninduced $(\mathrm{T}-)$ or induced $(\mathrm{T}+)$ with IPTG for $\triangle$ TMS-TatA overexpression. Lanes 3-6 show further processing of the cells in lane 2 . Lane 3 is the membrane pellet (TM) and lane 4 the water-soluble supernatant (S) following cell fractionation. Lanes 5 and 6 are the proteins from the soluble supernatant that were either not retained $(\mathrm{Ft})$ or bound $(\mathrm{Ni})$ to the $\mathrm{Ni}^{2+}$-affinity column. The molecular masses in kilodaltons of standard proteins, together with the positions to which they migrated, are shown to the side of the gel.

TatA. These data suggest that formation of certain $\alpha$-helical structures in TatA depends on the presence of the aminoterminal domain. Formation of these structures could be due to direct interaction with the amino-terminal region of the protein but could also be a consequence of the membrane integration or oligomerization mediated by the predicted helix $\alpha-1$.

Lipid Interactions of $\triangle T M S$-TatA. The possibility that $\Delta$ TMS-TatA can interact dynamically with a membrane was investigated using a method in which insertion of a protein into a phospholipid monolayer is detected as a change in surface pressure. Intact TatA cannot be analyzed by this technique since detergent is required to prevent aggregation of this protein. In the absence of a lipid monolayer, $\Delta \mathrm{TMS}$ TatA increased the measured surface pressure by $13 \mathrm{mN} / \mathrm{m}$. The monolayer experiments were all performed with the initial monolayer surface pressure greater than this value to ensure that only monolayer-specific effects were detected. The ability of $\Delta$ TMS-TatA to insert into lipid monolayers spread from a total E. coli polar lipid extract (which is composed of phosphatidylglycerol and phosphatidylethanolamine phospholipids together with cardiolipin), from 1,2dioleoyl-sn-glycero-3-phosphoglycerol (DOPG), from 1,2dioleoyl-sn-glycero-3-phosphoethanolamine (DOPE), or from 1,2-dioleoyl-sn-glycero-3-phosphocholine (DOPC) was measured as a function of increasing initial surface pressure (Figure 6A). $\triangle \mathrm{TMS}$-TatA was found to insert into monolayers spread from all lipid types but most strongly into a monolayer of anionic DOPG phospholipids. Even at initial surface pressures equal to or higher than the physiological membrane pressure of approximately $33 \times 10^{-3} \mathrm{~N} / \mathrm{m}(35)$, the membrane insertion could be observed. The observed level of insertion was decreased at increasing salt concentrations in the subphase buffer (Figure 6B), suggesting that the interaction had an electrostatic component. No membrane insertion was detected if the $\Delta$ TMS-TatA sample was first pretreated with proteinase $\mathrm{K}$, demonstrating that insertion depended on intact $\Delta$ TMS-TatA.
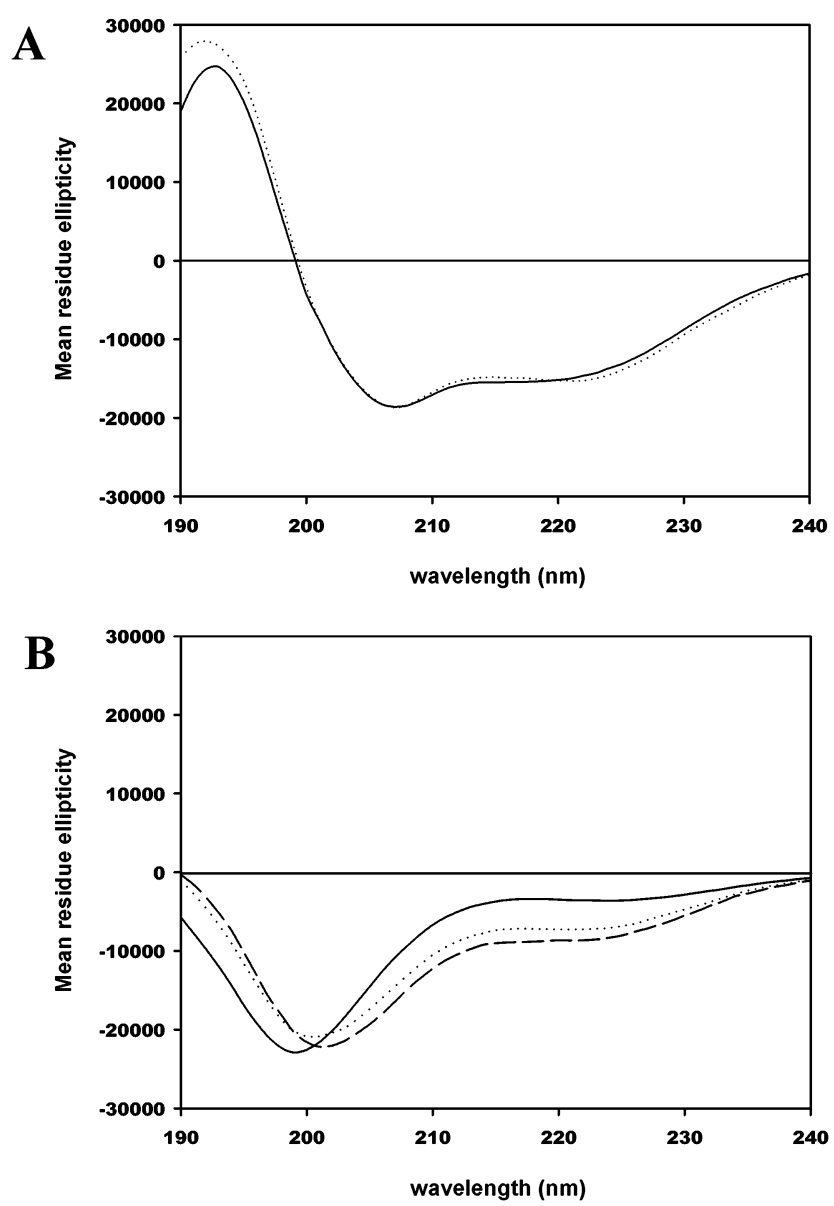

FIGURE 5: CD spectra of TatA and $\triangle T$ TMS-TatA. All spectra were recorded at $20^{\circ} \mathrm{C}$. (A) CD spectra of purified TatA at $0.65 \mathrm{mg} / \mathrm{mL}$ in $20 \mathrm{mM}$ MOPS (pH 7.2), $200 \mathrm{mM} \mathrm{NaCl}, 0.1 \%$ (w/v) $\mathrm{C}_{12} \mathrm{E}_{9}(-)$, and TatA in proteoliposomes at $0.7 \mathrm{mg} / \mathrm{mL}$ protein and a $1: 100$ protein:phospholipid ratio in $20 \mathrm{mM}$ MOPS (pH 7.2) and $200 \mathrm{mM}$ $\mathrm{NaCl}(\cdots)$. (B) CD spectra of purified $\triangle$ TMS-TatA at $2 \mathrm{mg} / \mathrm{mL}$ in $10 \mathrm{mM}$ Tris- $\mathrm{HCl}(\mathrm{pH} 7.5)$ either alone $(-)$ or incubated with liposomes formed from E. coli total polar lipids at either a 1:100 $(\cdots)$ or 1:200 (- - ) protein:phospholipid molar ratio.

Table 1: Secondary Structure Analyses (\%) of the CD Spectra Shown in Figure 5 with the Program DICHROWEB (25) Using the CDSSTR Algorithm and Reference Data Set $7(28)^{a}$

\begin{tabular}{lccccc}
\hline & helix & strand & turns & other & Nrmsd \\
\hline TatA detergent & 0.53 & 0.1 & 0.12 & 0.25 & 0.026 \\
TatA liposomes & 0.54 & 0.08 & 0.13 & 0.25 & 0.018 \\
$\Delta$ TMS-TatA & 0.04 & 0.09 & 0.07 & 0.79 & 0.013 \\
$\Delta$ TMS-TatA and lipos(1:100) & 0.19 & 0.11 & 0.12 & 0.59 & 0.011 \\
$\Delta$ TMS-TatA+lipos (1:200) & 0.23 & 0.14 & 0.17 & 0.48 & 0.011 \\
\hline
\end{tabular}

${ }^{a}$ The spectra that were analyzed were those of TatA in $\mathrm{C}_{12} \mathrm{E}_{9}$ detergent (TatA detergent), TatA in proteoliposomes (TatA liposomes), the $\Delta$ TMS-TatA fragment in aqueous solution $(\triangle T M S-T a t A)$, and the $\Delta$ TMS-TatA fragment in the presence of liposomes at a 1:100 or 1:200 protein:phospholipid molar ratio $[\Delta$ TMS-TatA+lipos(1:100) and $\Delta$ TMSTatA+lipos (1:200), respectively].

The membrane interaction of $\triangle \mathrm{TMS}$-TatA was further investigated using CD spectroscopy. $\triangle$ TMS-TatA was incubated in the presence of liposomes formed from total $E$. coli polar lipids for $2 \mathrm{~h}$ at $20^{\circ} \mathrm{C}$, and the $\mathrm{CD}$ spectrum was recorded. The CD spectrum of $\triangle$ TMS-TatA in the presence of liposomes is clearly significantly changed from that of the protein alone, with the appearance of a peak at approximately $224 \mathrm{~nm}$ indicating helix formation (Figure 5B). This experiment demonstrates that $\Delta \mathrm{TMS}$-TatA interacts 


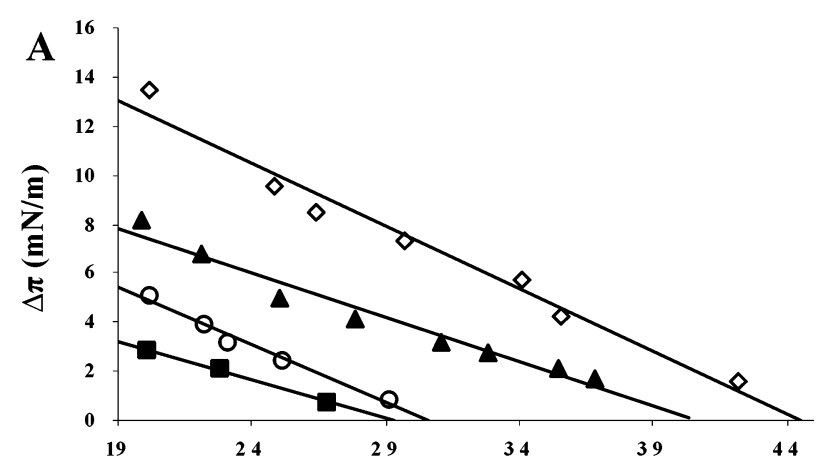

initial surface pressure $(\mathrm{mN} / \mathrm{m})$

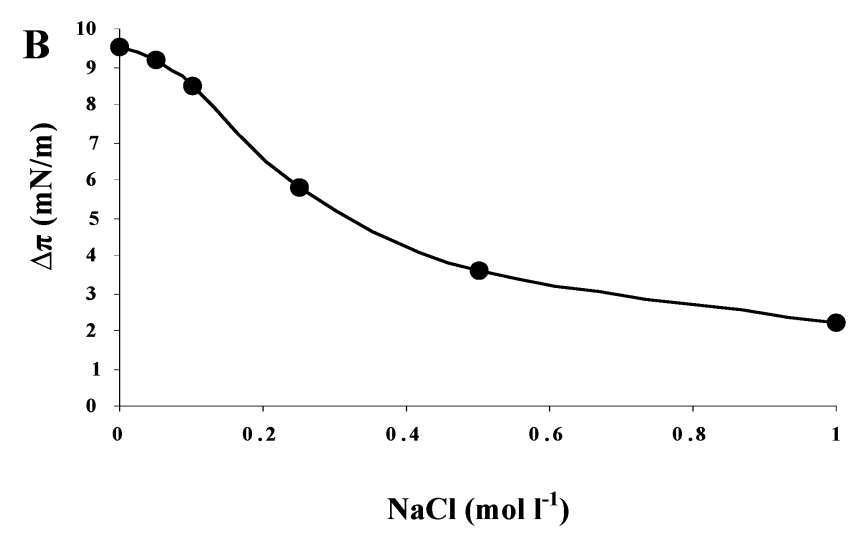

FIGURE 6: Insertion of $\triangle$ TMS-TatA into phospholipid monolayers. (A) Insertion was assessed as the surface pressure increase upon addition of $\triangle T M S-T a t A$ as a function of the initial surface pressure of the monolayer. Monolayers were spread from DOPG $(\diamond)$, total E. coli lipids $(\boldsymbol{\Delta})$, DOPE (O), or DOPC ( $\mathbf{\square})$. (B) Insertion of $\triangle \mathrm{TMS}$ TatA into a DOPG monolayer as a function of the increasing concentration of $\mathrm{NaCl}$ in the subphase buffer.

with membrane bilayers as well as monolayers. Secondary structure analysis shows that the liposomes increase the proportion of $\triangle$ TMS-TatA that is in an $\alpha$-helical conformation and correspondingly reduce the number of "unfolded" residues (Table 1). The exact helical content of liposomeassociated $\triangle$ TMS-TatA cannot be specified since it is not known what proportion of the total protein present is liposome-bound.

Topological Orientation of TatA. Strict application of the Positive-Inside rule (36) would suggest that TatA has an amino-terminal out orientation in the cytoplasmic membrane. However, the small size and unusual organization of TatA, together with the suggestion from electron microscopy studies that TatA has domains on either side of the membrane (11), make an experimental test of this model desirable. To this end, we attempted to determine the topological organization of TatA using protease accessibility measurements. Both spheroplasts (in which the physiological orientation of the cell membrane is retained) and inner membrane vesicles (in which the membrane is inverted relative to the physiological orientation) were prepared from cells expressing TatA. These membrane preparations were subjected to proteinase $\mathrm{K}$ treatment, and the fate of the TatA molecules present was assessed by immunoblotting. TatA in spheroplasts was insensitive to proteinase $\mathrm{K}$ treatment regardless of whether the spheroplasts had been prepared from cells with the wildtype Tat system, overexpressing TatA alone or overexpressing Tat $\mathrm{A}-\mathrm{E}$ (Figure 7A). This suggests that TatA is not
A

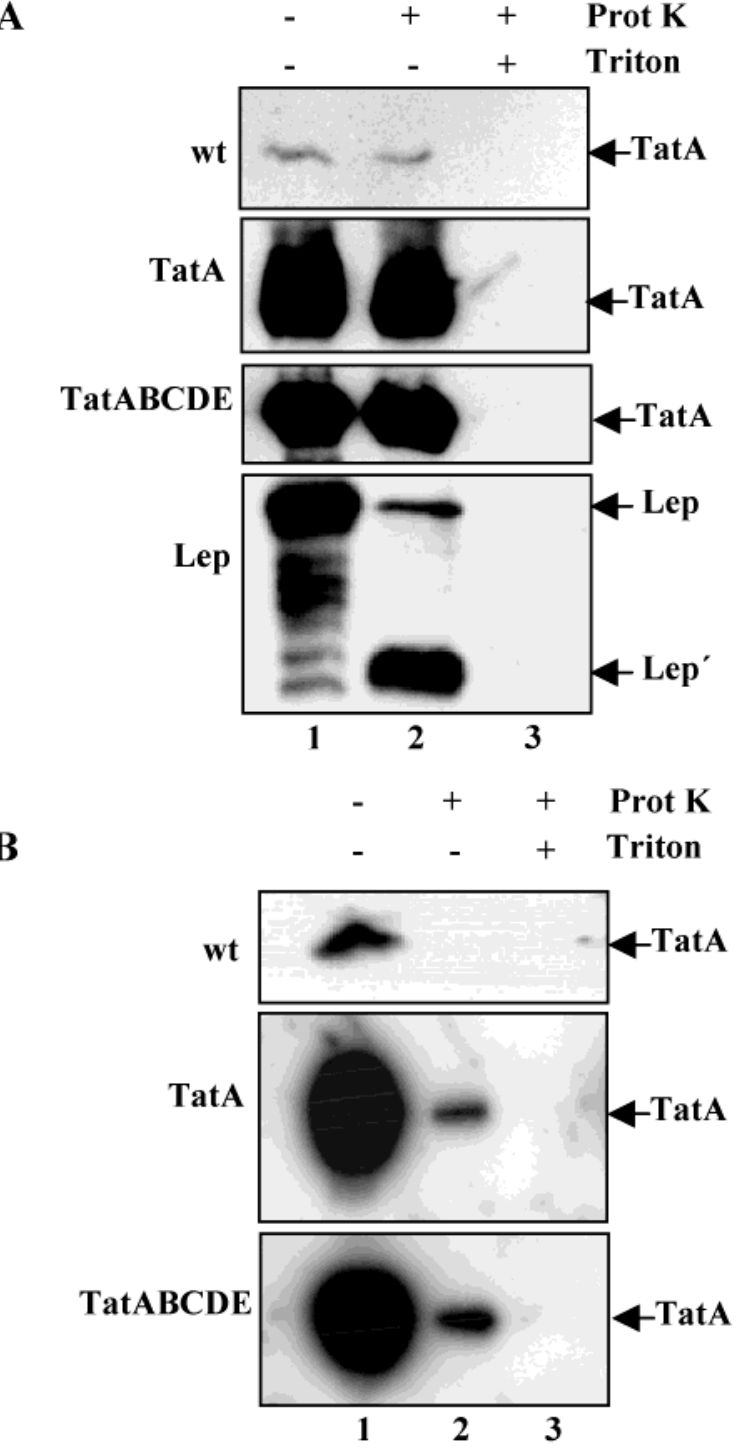

FIGURE 7: Topological organization of TatA probed by protease accessibility. Spheroplasts (A) or inner membrane vesicles (B) were prepared from cells expressing Tat proteins at wild-type levels (wt), overexpressing Tat $\mathrm{A}$ alone (TatA), overexpressing Tat $\mathrm{A}-\mathrm{E}$ (TatAB$\mathrm{CDE})$, or overexpressing leader peptidase (Lep). Aliquots $(50 \mu \mathrm{L})$ of the membrane preparations were incubated at $25^{\circ} \mathrm{C}$ for $30 \mathrm{~min}$ in the presence of $0.5 \mathrm{mg} / \mathrm{mL}$ proteinase $\mathrm{K}$ and/or $2 \%(\mathrm{v} / \mathrm{v})$ Triton $\mathrm{X}-100$ where indicated. Samples were subjected to precipitation with trichloroacetic acid and then analyzed by SDS-PAGE and immunoblotting using an antiserum directed against either TatA (panels wt, TatA, and TatABCDE) or leader peptidase (panel Lep). Lep' indicates the characteristic degradation product formed by digestion of the periplasmic domain of membrane-embedded leader peptidase by proteinase $\mathrm{K}$.

accessible from the periplasmic side of the membrane. Control experiments demonstrate that permeabilization of the spheroplast membrane with the detergent Triton X-100 renders TatA susceptible to proteolysis by proteinase $\mathrm{K}$ (Figure 7A). Degradation of the periplasmically accessible loop of leader peptidase by proteinase $\mathrm{K}$ (37) to produce a $19 \mathrm{kDa}$ product was used to demonstrate the efficacy of spheroplast preparation (Figure 7A). In contrast, TatA in inner membrane vesicles was readily degraded by proteinase $\mathrm{K}$ irrespective of the levels of TatA expression or of coexpression of other Tat proteins (Figure 7B), suggesting that TatA is exposed at the cytoplasmic side of the membrane. Taken together, these data indicate that under 
resting conditions the membrane extrinsic domain of TatA is located at the cytoplasmic side of the cell membrane.

\section{DISCUSSION}

We report here that the essential TatA component of the E. coli Tat translocation pathway can be purified as a highmolecular mass homooligomeric complex (Figures 2 and 3A). This observation is consistent with the detection of TatA self-self-interactions in chemical cross-linking studies in native E. coli membranes (12). While the cross-linking experiments were only able to demonstrate interactions between a maximum of four TatA protomers, the study presented here indicates that of the order of 40 TatA molecules can self-associate in a single complex. The TatA homooligomer did not require additional Tat components to form since the complex could be purified from a strain expressing TatA alone. However, the purified TatA complex has a lower molecular mass $(460 \mathrm{kDa})$ than the previously purified $\mathrm{Tat} \mathrm{AB}$ and Tat $\mathrm{ABC}$ complexes for which apparent molecular masses of at least $600 \mathrm{kDa}$ were reported $(11,14)$.

Our CD studies of purified TatA (Figure 5) are consistent with the secondary structure model for TatA shown in Figure 1 in which an amino-terminal transmembrane $\alpha$-helix is followed by an amphipathic $\alpha$-helix with the remainder of the molecule lacking major secondary structure elements. The role of the predicted amino-terminal helix has been investigated by characterizing a truncated form of TatA, termed $\triangle \mathrm{TMS}$-TatA, in which this helix has been deleted. These studies suggest that the amino-terminal helix has at least three functions: it anchors TatA to the membrane, it is necessary for the homooligomerization of TatA protomers, and it is required for formation of a properly folded structure. These functions may be linked since, as discussed below, formation of the predicted amphipathic helix might be driven by the membrane association of TatA mediated by the aminoterminal helix.

The Tat system functions to translocate folded polypeptides across the bacterial cytoplasmic membrane while maintaining the permeability barrier of the membrane to ions and other small molecules. Since the folded Tat substrate proteins have diameters of up to $65 \AA(4,5)$, transport must almost certainly be gated and involve conformational changes in the proteinaceous transport machinery. It is quite likely that these conformational changes will involve alterations in the interactions of Tat components with the membrane bilayer, and not surprisingly, the phospholipid composition of the cytoplasmic membrane is reported to strongly influence the efficacy of the Tat system (38). The TatA protein is thought to provide the bulk of the protein translocating channel (11) and therefore might have dynamic interactions with the phospholipids of the membrane bilayer. Particularly intriguing is the presence of a strongly predicted basic amphipathic $\alpha$-helix in TatA in which the basic residues are semiconserved (Figure 1). Such a structure could be located at the interface between the hydrophobic core of the bilayer and the (negatively charged) phospholipid headgroups but could oligomerize upon substrate binding to form a transmembrane channel with an aqueous interior and a hydrophobic exterior. Support for the idea that regions of TatA beyond the amino-terminal helix are capable of interacting with a membrane comes from experiments in which the
$\Delta$ TMS-TatA fragment was shown to insert into phospholipid monolayers at physiological surface pressure and ionic strength (Figure 6) and to associate with the bilayer membrane of liposomes (Figure 5B). Note that while $\Delta$ TMSTatA has little defined secondary structure in aqueous solution (Figure 5B), unfolded proteins per se do not exhibit membrane insertion in the monolayer technique used here (39). CD spectroscopy indicates that membrane association of the $\Delta$ TMS-TatA fragment induces some $\alpha$-helix formation in this otherwise unstructured protein (Figure 5B). This helical structure is most likely to be the predicted basic amphipathic helix $\alpha-2$ (Figure 1), the implication then being that this helix is stabilized by membrane association. The dependence of $\triangle$ TMS-TatA insertion into phospholipid monolayers on ionic strength (Figure 6B) and the increased level of interaction in the presence of anionic phospholipids (Figure 6A) would be consistent with a role for the basic residues of the amphipathic helix in the membrane interaction. The observed preference for $\Delta$ TMS-TatA interaction with a monolayer formed from phosphatidylglycerol is consistent with the reported dependence of in vivo Tat transport on anionic phospholipids (38). The interaction of the $\Delta$ TMS-TatA region with the membrane is expected to be reinforced in full-length TatA since the $\Delta$ TMS-TatA region will also be localized to the membrane by the aminoterminal helix. In addition, energization of the cytoplasmic membrane and the presence of other Tat components and of the substrate protein could all influence the membrane interactions of TatA.

Since protein transport is a vectorial process, the topological organization of TatA is likely to be crucial to its function. Here we found that TatA, even in a wild-type Tat background, was accessible to protease digestion from the cytoplasmic, but not the periplasmic, side of the cell membrane (Figure 7). With the proviso that this method only probes the accessibility of those regions of TatA recognized by the polyclonal antiserum used in the experiments, we conclude that the extramembranous region of resting TatA is found at the cytoplasmic side of the membrane. This is consistent with the observation that the chloroplast TatA homologoue Tha4 is accessible to proteases and antibodies at the stromal (equivalent to cytoplasmic) side of the thylakoid membrane (40). It remains possible that the topology of TatA could change during the transport cycle.

\section{ACKNOWLEDGMENT}

We thank Dr. Bob Sarra for assistance with the circular dichroism experiments, Dr. Frank Sargent for advice on subcellular fractionation, and Dr. Jan-Wilhelm de Gier for providing the leader peptidase expression plasmid and antileader peptidase antiserum.

\section{REFERENCES}

1. Pugsley, A. P. (1993) Microbiol. Rev. 57, 50-108.

2. Manting, E. H., and Driessen, A. J. (2000) Mol. Microbiol. 37, 226-238.

3. Berks, B. C. (1996) Mol. Microbiol. 22, 393-404.

4. Berks, B. C., Sargent, F., and Palmer, T. (2000) Mol. Microbiol. 35, 260-274.

5. Sargent, F., Berks, B. C., and Palmer, T. (2002) Arch. Microbiol. $178,77-84$.

6. Mori, H., and Cline, K. (2001) Biochim. Biophys. Acta 1541, 8090. 
7. Bogsch, E., Sargent, F., Stanley, N. R., Berks, B. C., Robinson, C., and Palmer, T. (1998) J. Biol. Chem. 273, 18003-18006.

8. Sargent, F., Bogsch, E., Stanley, N. R., Wexler, M., Robinson, C., Berks, B. C., and Palmer, T. (1998) EMBO J. 17, 3640-3650.

9. Sargent, F., Stanley, N. R., Berks, B. C., and Palmer, T. (1999) J. Biol. Chem. 274, 36073-36082.

10. Weiner, J. H., Bilous, P. T., Shaw, G. M., Lubitz, S. P., Frost, L., Thomas, G. H., Cole, J. A., and Turner, R. J. (1998) Cell 93, 93- 101 .

11. Sargent, F., Gohlke, U., de Leeuw, E., Stanley, N. R., Palmer, T., Saibil, H. R., and Berks, B. C. (2001) Eur. J. Biochem. 268, 33613367.

12. de Leeuw, E., Porcelli, I., Sargent, F., Palmer, T., and Berks, B. C. (2001) FEBS Lett. 506, 143-148.

13. Jack, R. L., Sargent, F., Berks, B. C., Sawers, G., and Palmer, T. (2001) J. Bacteriol. 183, 1801-1804.

14. Bolhuis, A., Mathers, J. E., Thomas, J. D., Barrett, C. M., and Robinson, C. (2001) J. Biol. Chem. 276, 20213-20219.

15. Cline, K., and Mori, H. (2001) J. Cell Biol. 154, 719-729.

16. Mori, H., and Cline, K. (2002) J. Cell Biol. 157, 205-210.

17. Miroux, B., and Walker, J. E. (1996) J. Mol. Biol. 260, 289-298.

18. Casadaban, M. J., and Cohen, S. N. (1979) Proc. Natl. Acad. Sci. U.S.A. 76, 4530-4533.

19. de Vrije, T., Tommassen, J., and de Kruijff, B. (1987) Biochim. Biophys. Acta 900, 63-72.

20. Johnson, M. L., Correia, J. J., Yphantis, D. A., and Halvorson, H. R. (1981) Biophys. J. 36, 575-588.

21. Cohn, E. J., and Edsall, J. T. (1943) in Proteins, Amino Acids and Peptides as Ions and Dipolar Ions, pp 370-381, Reinhold, New York.

22. Collinson, I., Breyton, C., Duong, F., Tziatzios, C., Schubert, D., Or, E., Rapoport, T., and Kühlbrandt, W. (2001) EMBO J. 20, 2462-2471.

23. Schubert, D., Tziatzios, C., van den Broek, J. A., Schuck, P., Germeroth, L., and Michel, H. (1994) Prog. Colloid Polym. Sci. 94, 14-19.
24. Savitsky, A., and Golay, M. J. E. (1964) Anal. Chem. 36, 16271639.

25. Lobley, A., Whitmore, L., and Wallace, B. A. (2002) Bioinformatics 18, 211-212.

26. Mao, D., Wachter, E., and Wallace, B. A. (1982) Biochemistry 21, 4960-4968.

27. Brahms, S., and Brahms, J. (1980) J. Mol. Biol. 138, 149-178.

28. Johnson, W. C., Jr. (1999) Proteins: Struct., Funct., Genet. 35, $307-312$.

29. Demel, R. A. (1974) Methods Enzymol. 32, 539-545.

30. Laemmli, U. K. (1970) Nature 227, 280-285.

31. Towbin, H., Staehlin, T., and Gordon, J. (1979) Proc. Natl. Acad. Sci. U.S.A. 76, 4350-4354.

32. Jones, D. T. (1999) J. Mol. Biol. 292, 195-202.

33. Settles, A. M., Yonetani, A., Baron, A., Bush, D. R., Cline, K., and Martienssen, R. (1997) Science 278, 1467-1470.

34. Wexler, M., Sargent, F., Jack, R. L., Stanley, N. R., Bogsch, E. G., Robinson, C., Berks, B. C., and Palmer, T. (2000) J. Biol. Chem. 275, 16717-16722.

35. Demel, R. A. (1994) Subcell. Biochem. 23, 83-120.

36. von Heijne, G. (1992) J. Mol. Biol. 225, 487-494.

37. de Gier, J. W., Mansournia, P., Valent, Q. A., Phillips, G. J., Luirink, J., and von Heijne, G. (1996) FEBS Lett. 399, 307-309.

38. Mikhaleva, N. I., Santini, C. L., Giordano, G., Nesmeyanova, M. A., and Wu, L. F. (1999) FEBS Lett. 463, 331-335.

39. van't Hof, R., van Klompenburg, W., Pilon, M., Kozubek, A., de Korte-Kool, G., Demel, R. A., Weisbeek, P. J., and de Kruijff, B. (1993) J. Biol. Chem. 268, 4037-4042.

40. Ma, X., and Cline, K. (1999) J. Biol. Chem. 275, 10016-10022.

BI026142I 